\title{
Examining the Reading Aloud Speeds of the Secondary School Students
}

\author{
Gulsah Mete (D) \\ Assistant Professor, Department of Turkish Education, Educational Sciences Institute, Karamanoglu Mehmetbey \\ University, Turkey. \\ Email: gulsahmete@kmu.edu.tr.Tel:05378819584
}

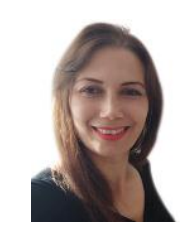

\begin{abstract}
Having a critical role in both academic and social lives, reading fast and comprehension are necessary skills for today's individuals. The factors affecting these skills of adolescent learners are needed to examine. With an intention to provide significant results to the literature, this study aimed to examine if there is a difference between the secondary school students' reading aloud speeds and the variations as the type of the text, their gender, and their classroom levels. 40 students, of whom were 20 girls and 20 boys, from a secondary school attended to the study. They varied across the classroom levels as well. Accordingly, 10 of those students were 5 th, 10 of them were 6 th, 10 of them were 7 th, and 10 of them were 8 th graders. In order to collect data, a narrative text (a story) and an informative text (an essay) were utilized to test the students' reading aloud speeds. The findings were obtained through the standard deviation calculations. Accordingly, the study revealed that the reading speeds of the secondary school students change according to the text type, their gender and classroom levels.
\end{abstract}

Key words: Reading, Reading fast, Reading aloud speed, Factors affecting reading speed, Story, Essay.

Citation | Gulsah Mete (2020). Examining the Reading Aloud Speeds of the Secondary School Students. Asian Journal of Education and Training, 6(4): 664-670.

History:

Received: 26 October 2020

Revised: 16 November 2020

Accepted: 27 November 2020

Published: 10 December 2020

Licensed: This work is licensed under a Creative Commons

Attribution 3.0 License (oc) EY

Publisher: Asian Online Journal Publishing Group
Funding: This study received no specific financial support

Competing Interests: The author declares that there are no conflicts of interests regarding the publication of this paper.

Transparency: The author confirms that the manuscript is an honest, accurate, and transparent account of the study was reported; that no vital features of the study have been omitted; and that any discrepancies from the study as planned have been explained.

Ethical: This study follows all ethical practices during writing.

\section{Contents}

1. Introduction

2. Method

3. Findings 


\section{Contribution of this paper to the literature}

This study contributes to existing literature by examining if there is a difference between the secondary school students' reading aloud speeds and the variations as the type of the text, their gender, and their classroom levels.

\section{Introduction}

Reading is an action carried out to be able to gain knowledge. Reading which is a language skill utilized by physical and mental components has been defined differently: While according to Ozdemir (1990) reading skill is a mental activity ensuring the comprehension and interpretation of the printed words, it is the vocalization of the written and printed symbols compliance with certain rules according to Rozan (1982) and Sever (2004). Whereas (Harris \& Sipay, 1990) have defined reading skill as the interpretation of the written language in a meaningful way, Smith and Dechant (1961) have pointed out that reading is the process embodying the recognition and perception of the cognitive interpretation process. To sum up, reading skill is a physical and a mental process comprising the perception, understanding, comprehension and interpretation.

Reading skill enabling the comprehension skills of human beings has been acquired at the start of primary school. In the primary school years, reading strategies such as reading aloud, reading silently, timed reading are applied to increase the speed of reading skill. On the other hand, it is known that the process of gaining knowledge through reading has been intensified since $4^{\text {th }}$ grade, and consequently more efficient reading and comprehension practices are common in use. Also, improving reading skill practices are proceeded in secondary school. In the $5^{\text {th }}$ grade, reading aloud must be followed at one-third in ratio and this ratio should be decreased in the following grades (Aytaş, 2005). Both reading fast and comprehending what has been read are necessary skills today's individuals should have, which is an essential factor enabling students' achievement in not only social but also academic lives. Students, who read fast, comprehend correctly, interpret and use the language efficiently as well as with a rich variety of vocabulary, learn more easily in every field and achieve at steady and highest levels.

Reading aloud can be defined as the vocalization of perceived and comprehended words or phrases according to their semantic and phonetic features through speaking organs as well as reading a written material to the audience within a hearing tone (Aktas \& Gündüz, 2002; Oz, 2011). Reading aloud which is pronouncing the vocabulary aloud while reading a text has a pivotal role in one's both daily and academic lives. Reading aloud is known as an important reading strategy in the acquisition of reading with fluency skills (Okur, 2013; Yllmaz, 2018). Particularly it underpins the first reading and writing practices during the primary school years. Reading aloud practices are implemented for the reasons which are to determine students' reading improvements, to ensure students acquire a standard speaking skill, to build a foundation for reading silently and to develop students' interpersonal skills. In reading aloud, it is essential to maintain students pronounce correctly and read with fluency. It also contributes to the improvement of students' speaking skills. Reading with accuracy compliance with pronunciation rules have great contributions to speaking with accuracy and proficiency as well (Cifci, 2000; Ozbay, 2009).

It is vital to read the material compliance with the characteristics of language as well as with accuracy in reading aloud. How great attention is given to speaking, reading needs that much attention also. In reading aloud, listeners are also motivated and enjoy. Some complex ideas and feelings can be understood easily through engagement with reading aloud also. At the same time, the language of the text read, its easiness to understand and fluency give enjoyment to listeners, which contributes to students' listening skill improvement and helps them become a good listener (Kavcar, 1995). According to Güneş (2007), reading aloud generates the functions of the brain's several parts. Therefore, it has many effects on the improvement of students' language skills and their mental activities. The studies indicate that students should engage in reading a text aloud once a day at least.

Reading aloud has several benefits: The student who reads aloud gives attention to reading, concentrates on reading, comprehends better and interprets, which eventually increases the student's confidence and builds selfcontrol over his/her reading and comprehension as well as self-guidance. Besides, some activities about the text read aloud help students comprehend the text better and improve their speaking skills. Some activities such as pointing out the feelings and ideas of the text differently, acting the text out, dramatizing it, using facial expressions and gestures in reading can be done. Students at all school levels (primary, secondary and even high school) should be encouraged to read aloud frequently. Since both eyes and ears are active in reading aloud, it increases the comprehension and assists learning besides memorization to occur swiftly (Aktas \& Gündüz, 2002; Beyreli, Çetindağ, \& Celepoğlu, 2010; Lane \& Wright, 2007).

There are some concerns needed to be taken in reading aloud: After the education of literacy, students should not be allowed to use their body language such as hand, arm, and head movements inappropriately. Students should be encouraged not to use their local dialects in reading and speaking. Teacher should introduce the correct and appropriate intonation in reading aloud, and also s/he should use Turkish language efficiently while reading aloud as a model. The texts to be read should not include unknown vocabulary as much as possible. Before reading aloud, adequate time should be given to students so that they can comprehend the text easily and they should be allowed to read it silently at first. Teacher reading aloud not only becomes a role-model but also helps them focus on the text, and consequently enables them to enjoy the text, which has been read effectively. Teacher should present the ideas and feelings in the text by dramatizing it and motivating students. By doing this, student recognizes and comprehends the ideas and feelings in the text easily. The needed feedback on student's reading should be given after s/he finishes reading. Moreover, students' vocabulary should be enriched through reading aloud strategy (Celik, 2006; Yılmaz, 2018).

According to Maviş (2005) reading speed is a specific unit of time which is the between the start of read a text with comprehension and finishing it. The common technique to test reading speed is the number of the word per minute read with comprehension. Reading fast, which is reading more words with comprehension in a specific unit of time, is needed because of the reasons such as accommodating ourselves to the world, catching up with the improvements, and having achievements etc. Reading fast can be influenced by the factors such as the type of the text, the purpose of reading, language and mental developments or physical environment etc. (Akyol, 2013; Kurudayıŏlu \& Soysal, 2015; Ozbay, 2009). The typical reading rate is 150 words per minute (Korkmaz, 2008). 
Additionally, according to Gray (1975), student increases his/her rate in the first three years after acquiring literacy. This rate can rise from $60 \mathrm{wpm}$ to $160 \mathrm{wpm}$. However, reading aloud rate might decrease in the following years.

As stated by Baştuğ and Akyol (2012), the reading rate is obtained through the following steps: the total number of words per minute read by a student is calculated and the number of mispronounced words is subtracted from the total number. Consequently, the number of words read correctly by students is detected. Reading fast is as important as reading with accuracy, which is a prerequisite for reading with fluency and reading comprehension.

On the other hand, Akçamete (1999) points out that it is not so effective to detect only the number of letters or words per minute for reading rate. To test the reading rate, the followings below should be regarded:

- The time of the start is noted down before reading aloud.

- The text is read.

- The time of finishing the text is also written down. The duration is indicated by seconds.

- The number of words in the text is divided by the duration of reading, and the reading rate is calculated. The result is multiplied by 60 .

- The result of the multiplication is the number of words per minute.

The factors affecting the reading rate can be listed as follows (Ruşen, 2016):

- The easiness or sophistication of the text to be read,

- The reader's vocabulary knowledge,

- The readiness and cultural level of the reader,

- The reader's reading comprehension skills,

- The reader's eye health and his/her education for improving eye movements.

However, the factors affecting the reading rate negatively can be arrayed as follows (Dilligil, 2004; Imrak, 2006; Kondu, 2008):

- Reading with a high-pitched tone and subvocalization,

- Reading the words one by one or reading with syllabification,

- Focusing on details and regression,

- Reading passively,

- The anxiety of not comprehending the text when read fast.

- Lack of education on eye movements,

- Cultural background, lack of grammar or vocabulary education,

- Concentration problems.

According to Baran (2008) those students who are able to read fast have the qualifications below:

- They have the habit of reading.

- The students with a habit of reading have a rich vocabulary knowledge, express themselves efficiently, and interact with effective communication.

- They have adequate time for not only their assignments but also other activities as they read fast.

- Since they read fast and comprehend, they solve more problems not only for the preparation of the exams but also in the exams, which increases their self-confidence.

- The students with reading fast skills live achievements consistently in their both academic and social lives.

In order to increase students' reading speeds, first of all, it is required that students should gain a habit of reading. Teaching how to use their eye movements, they can expand their focal range. They are supported with the practices and the materials such as books, texts etc. regarding the reading purpose.

\section{Method}

\subsection{Research Design}

The study adopted the case study from qualitative methods. The case study is a design in which an in-depth analysis of a case or an event in its natural setting is developed and the data is collected in a systematic way (Davey, 2009; Yıldırım \& Simşek, 2013). The results obtained through the case study indicate the reasons why that case or event has occurred in that way as well as the considerations to be taken in further studies.

\subsection{The Aim of the Study}

This study has aimed to understand if there is a significant difference between the secondary school students' reading speeds and the variations as the type of the text, their gender, and their classroom levels. In order to address this aim, the followings have been intended to reach in the study:

- To determine the 5 th, $6^{\text {th }}, 7^{\text {th }}$ and $8^{\text {th }}$ graders' number of words per minute in reading texts in the forms of story and essay.

- To determine if the secondary school students' reading aloud speeds change according to.

- The text in the form of a story.

- The text in the form of an essay.

- The students' gender.

- The students' classroom levels.

\subsection{Data Collection}

The participants of the study were 40 students from Mehmet Akpinar Secondary School during the fall of the 2018-2019 academic years, of whom were 20 girls and 20 boys. They varied across the classroom levels as well. So, 10 of those students were $5^{\text {th }}, 10$ of them were $6^{\text {th }}, 10$ of them were $7^{\text {th }}$, and 10 of them were $8^{\text {th }}$ graders. 


\subsection{The Instruments}

The narrative and informative texts utilized in the study were selected from the texts used in the secondary school course books regarding the average word numbers they included. The texts in the Turkish course books were reviewed in order to determine the texts to be implemented in the study. An informative text and a narrative one, which are used in all the classroom levels, were selected, and then, it was consulted to two Turkish teachers for their expert opinions. By regarding the expert opinions, these texts were decided to use in the study. Accordingly, the narrative text in the form of a story named as "Emine Teyze'nin Çilek Reçeli" and the informative text in the form of an essay named as "Güler Yüz" were utilized in the study.

The data of the study were gathered in the Turkish courses by the researcher, in which each student read aloud the texts one by one. The researcher used a timer for a minute, and she recorded the student's reading. After that, the researcher examined the recordings, and she measured the number of words per minute read correctly by each student.

\subsection{Data Analysis}

The findings on the changes between the reading aloud rate of the participants and the variations as the type of the text, gender and classroom levels were obtained by measuring the standard deviations. After obtaining the students' wpm scores, the researcher displayed them in the tables by considering the type of the text, gender and classroom levels. Then, interpretation and discussions on these tables have been presented.

\section{Findings}

3.1. The WPM Scores of the Girls and Boys in the $5^{\text {th }}, 6^{\text {th }}, 7^{\text {th }}$ And $8^{\text {th }}$ Grades in the Story and Essay.

Table-1. The WPM scores of the girls and boys in the $5^{\text {th }}$ grade in the story and essay.

\begin{tabular}{c|c|c}
\hline \multicolumn{2}{|c|}{ The wpm scores in the story } & The wpm scores in the essay \\
\cline { 1 - 3 } Girls & & 118 \\
\hline 1. & 103 & 148 \\
\hline 2. & 140 & 121 \\
\hline 3. & 120 & 145 \\
\hline 4. & 108 & 108 \\
\hline 5. & 108 & 134 \\
\hline Boys & & 142 \\
\hline 1. & 138 & 91 \\
\hline 2. & 136 & 122 \\
\hline 3. & 99 & 79 \\
\hline 4. & 122 & \\
\hline 5. & 94 & \\
\hline
\end{tabular}

According to the Table 1, the highest wpm score of the girls in the $5^{\text {th }}$ grade is 140 in the story while the lowest score is 103. Regarding the essay, the girls' highest wpm score is 148 and the lowest score is 108. The girls in $5^{\text {th }}$ grade have scored the highest wpm in the essay compared to the story. The boys' highest wpm score is 138 in the story, and the lowest wpm score is 94 . On the other hand, in the essay, the highest wpm score is 142 and the lowest wpm is 79 . Hence, the boys in the $5^{\text {th }}$ grade have read more words correctly in the essay compared to the ones in the story. These findings indicate that both the girls and boys in the $5^{\text {th }}$ grade have read more words correctly in the essay.

Table-2. The WPM scores of the girls and boys in the $6^{\text {th }}$ grade in the story and essay.

\begin{tabular}{c|c|c}
\hline \multirow{2}{*}{$\mathbf{6}^{\text {th }}$ grade } & The wpm scores in the story & The wpm scores in the essay \\
\hline Girls & 104 & 137 \\
\hline 1. & 130 & 140 \\
\hline 2. & 106 & 114 \\
\hline 3. & 135 & 161 \\
\hline 4. & 109 & 134 \\
\hline 5. & & 134 \\
\hline Boys & 109 & 161 \\
\hline 1. & 138 & 121 \\
\hline 2. & 113 & 108 \\
\hline 3. & 111 & 131 \\
\hline 4. & 130 & \\
\hline 5. & &
\end{tabular}

As seen in the Table 2, in the story, the highest wpm score of the girls in the $6^{\text {th }}$ grade is 135 and the lowest score is 104. In the essay, the highest score is 161 and the lowest wpm is 114 . The girls in the $6^{\text {th }}$ grade have read more words correctly in the essay compared to the story. The boys in the $6^{\text {th }}$ grades have scored the highest as 138 wpm while the lowest as 109 wpm in the story. In the essay, the highest wpm score is 161 and 108 is the lowest wpm. As similar to the girls, they have read more words correctly in the essay compared to the story. According to these findings, the girls and boys at the $6^{\text {th }}$ grade have read more words in the essay. 
Table-3. The WPM scores of the girls and boys in the $7^{\text {th }}$ grade in the texts in story and essay.

\begin{tabular}{c|c|c}
\hline $\boldsymbol{7}^{\text {th }}$ Grades & The wpm scores in the story & The wpm scores in the essay \\
\hline Girls & 172 & 182 \\
\hline 1. & 154 & 175 \\
\hline 2. & 157 & 161 \\
\hline 3. & 177 & 169 \\
\hline 4. & 170 & 154 \\
\hline 5. & & 96 \\
\hline Boys & 140 & 102 \\
\hline 1. & 101 & 183 \\
\hline 2. & 156 & 114 \\
\hline 3. & 115 & 95 \\
\hline 4. & 119 & \\
\hline 5. & &
\end{tabular}

According the Table 3, in the story, the highest wpm score of the girls in the $7^{\text {th }}$ grade is 177 and the lowest score is 154 . In the essay, the highest score is 182 and the lowest wpm is 154 . The girls in the $7^{\text {th }}$ grade have read more words correctly in the essay compared to the story. The boys have scored the highest as 156 wpm while the lowest as $101 \mathrm{wpm}$ in the story. In the essay, the highest wpm score is 183 and 96 is the lowest wpm. As similar to the girls, the boys in the $7^{\text {th }}$ grade have read more words correctly in the essay compared to the story. According to these findings, the girls and the boys in the $7^{\text {th }}$ grade have read more words in the essay.

Table-4. The WPM scores of the girls and boys in the $8^{\text {th }}$ grade in the story and essay.

\begin{tabular}{c|c|c}
\hline \multicolumn{2}{c|}{ The wpm scores in the story } & The wpm scores in the essay \\
\hline Girls & 111 & 122 \\
\hline 1. & 138 & 158 \\
\hline 2. & 145 & 141 \\
\hline 3. & 120 & 133 \\
\hline 4. & 113 & 133 \\
\hline 5. & & 159 \\
\hline Boys & 157 & 108 \\
\hline 1. & 107 & 127 \\
\hline 2. & 142 & 154 \\
\hline 3. & 157 & 139 \\
\hline 4. & 143 & \\
\hline 5. & &
\end{tabular}

According the Table 4, in the story, the highest wpm score of the girls in the $8^{\text {th }}$ grade is 145 and the lowest score is 113 . In the essay, the highest wpm is 158 and the lowest wpm is 122 . The girls in the $8^{\text {th }}$ grade have read more words correctly in the essay compared to the story. The boys have scored the highest as 157 wpm while the lowest as $107 \mathrm{wpm}$ in the story. In the essay, the highest wpm score is 159 and 108 is the lowest wpm. As similar to the girls, the boys in the $8^{\text {th }}$ grade have read more words correctly in the essay compared to the story. According to these findings, the girls and boys in the $8^{\text {th }}$ grade have read more words correctly in the essay.

3.2. The Average Wpm Scores of the Secondary School Students According to the Type of the Text and their Gender.

Table-5. The average wpm scores of the secondary school students according to the type of the text and their gender.

\begin{tabular}{c|c|c|c|c}
\hline \multicolumn{2}{c}{ Girls (The Average Wpm Score) } & \multicolumn{2}{c}{ Boys (The Average Wpm Score) } \\
\hline & Story & Essay & Story & Essay \\
\hline 5. & 115.8 & 128 & 117.8 & 113.6 \\
\hline 6. & 116.8 & 137.2 & 120.2 & 131 \\
\hline 7. & 166 & 168.2 & 126.2 & 118 \\
\hline 8. & 125.4 & 137.4 & 141.2 & 137 \\
\hline
\end{tabular}

According to the Table 5 , in the story, the average wpm scores of the girls in the $5^{\text {th }}, 6^{\text {th }}$ and $7^{\text {th }}$ grades tend to rise, there is a fall in the $8^{\text {th }}$ grade compared to the wpm scores in the $7^{\text {th }}$ grade. On the other hand, in the essay, the girls' average wpm scores appear to be rising from $5^{\text {th }}$ to $8^{\text {th }}$ grade. There seems to be a difference between the average wpm scores of the girls and the type of the text, and the tendency of rising in the essay has not been detected in the story.

As seen in the Table 5, while reading the story, a rising in the average wpm scores of the boys from $5^{\text {th }}$ to 8 grades has been detected. In the essay, the average wpm scores have risen in $5^{\text {th }}, 6^{\text {th }}$ and $8^{\text {th }}$ grades, however, there is a fall in the $7^{\text {th }}$ grade. There appears to be a difference between the average wpm scores of the boys and the type of the text, and the rising in the average wpm score in the story has not been detected in the essay.

Shortly, the Table 5 displays the difference between the average wpm scores and the types of the text. The rise in the girls' average wpm scores while reading the essay have not been detected in reading the story, which is quite opposite considering the boys' average wpm scores. The boys' average wpm scores have risen in the story, however, any rise has not been observed in the essay. 
3.3. The Average Wpm Scores of the Secondary School Students According to their Classroom Levels.

Table-6. The average wpm scores of the secondary school students according to their classroom levels.

\begin{tabular}{c|c|c}
\hline Classroom levels & The average wpm scores in the story & $\begin{array}{c}\text { The average wpm scores in the } \\
\text { essay }\end{array}$ \\
\hline 5. & 116.8 & 120.8 \\
\hline 6. & 118.5 & 134.1 \\
\hline 7. & 146.1 & 143.1 \\
\hline 8. & 133.3 & 137.2 \\
\hline
\end{tabular}

According to the Table 6, the average wpm scores of the secondary school students appear to be rising in the $5^{\text {th }}, 6^{\text {th }}$ and $7^{\text {th }}$ grades considering both of two text types. However, there seems to be a fall in the $8^{\text {th }}$ grader's average wpm scores.

\section{Discussion and Results}

This study has aimed to investigate if there is a difference between the secondary school students' reading speeds and the type of the text, their gender, and their classroom levels. In order to address this aim, the study was conducted and the following results have been obtained:

Both the girls and boys in the $5^{\text {th }}, 6^{\text {th }}, 7^{\text {th }}$ and $8^{\text {th }}$ grades have read more words correctly in the essay. The girls' wpm scores have indicated a difference considering the type of the text and the rising tendency in the essay has not been detected in the story. On the other hand, by indicating a difference between the boys' wpm scores and the type of the text, the rise in the story has not been detected in the essay. Consequently, there is a difference between the secondary school students' reading speeds and the type of the text. The girls' average wpm scores have risen in the essay, but any rise has not been observed in the story, which is quite opposite regarding the boys' average wpm scores. The boys' average wpm scores have risen in the story however, any rise has not been detected in the essay. Considering the classroom levels, a rising in the wpm scores of $5^{\text {th }}, 6^{\text {th }}$, and $7^{\text {th }}$ graders has been seen in the both of the text types, but $8^{\text {th }}$ graders' wpm scores have fallen compared to the previous class level.

Whereas $5^{\text {th }}$ graders' highest wpm score is 116 in the essay, and 120 in the story, the $8^{\text {th }}$ graders have scored 137 in the essay and 133 in the story. By regarding these findings, the reading speed appears to be changing according to the classroom levels, which agrees with the results of the study named "Determination of Reading Comprehension Levels of Fourth Grade Students in Terms of Some Variable” by Değirmenci Gündoğmuş (2018). According to this study, it was found out that $4^{\text {th }}$ graders read the informative texts in a shorter time than the narrative texts. Moreover, in the study by Blommers and Lindquist (1954), there is a significant difference between the type of the text and the reading speed, and reading comprehension level. The reading speed has a tendency of fall in the informative texts, which disagrees with the result of this study.

While the reading speed has increased depending on the classroom levels, it has decreased in the $8^{\text {th }}$ grade by considering $7^{\text {th }}$ grade. In their study on the reading speed, Stanovich, Nathan, and Zolman (1988) state that the reading speed has a tendency in rising with the chronological age and particularly in the $5^{\text {th }}$ grade, this occurs faster. On the other hand, Carver (1989) points out that each individual has his/her own reading level however, the wpm increases about 10-20 words with the chronological age after acquiring the literacy. In this study, the average wpm scores have increased in the $5^{\text {th }}, 6^{\text {th }}$ and $7^{\text {th }}$ grades. Although this finding seems to have an agreement with the studies mentioned earlier, there is a fall in the wpm scores of the $8^{\text {th }}$ graders, and this result disagrees with the studies.

The boys' average wpm scores in the informative and narrative texts have indicated a change considering the classroom levels in contrast with the girls. The girls' wpm scores in the informative text are higher than the boys'. Similarly, Armut and Türkyılmaz. (2017) have revealed that the variation as the gender has an impact on the students' reading with fluency. Another study by Armut (2017) has indicated that the girls outperform the boys in reading with fluency. These studies support the result of the study. Nevertheless, not only (Sahin, 2011) but also Keskin (2012) have reached that the gender does not have any impact on the reading speed and reading with accuracy. This study's result disagrees with these studies indicating the variation of the gender's no an impact role.

As a conclusion, the study has concluded that there is a difference between the secondary school students' reading speeds and the type of the text, their gender and their classroom levels.

\section{Implications}

This study might be conducted with different students at primary, high school and university by using different kinds of texts. The further studies on the reasons of the decrease in the $8^{\text {th }}$ graders' wpm scores might be examined. The activities to increase the students' wpm scores can be done. In order to encourage students to achieve reading aloud effectively, more example reading activities by the classroom and Turkish can be suggested. Additionally, listening as well as reading aloud activities on literal texts can be done.

\section{References}

Akçamete, G. (1999). Effective and speed reading: "How can we improve reading? Ankara: Aydoğdu Offset.

Aktas, S., \& Gündüz, O. (2002). Written and verbal expression. Ankara: Akçağ Publications.

Akyol, H. (2013). Turkish teaching methods (3rd ed.). Ankara: PegemA Publishing.

Armut, M. (2017). Investigation of secondary school students' fluent reading skills in terms of various variables (Yozgat City Example). Master's Thesis, Ahi Evran University / Institute of Social Sciences, Kırşehir.

Armut, M., \& Türkyılmaz., M. (2017). Examining fluent reading skills of secondary school students in terms of various variables. Ahi Evran University Kirşehir Faculty of Education Journal, 18(3), 348-375.

Aytaş, G. (2005). Reading education. Turkish Journal of Educational Sciences, 3(4), 461-470.

Baran, Z. (2008). Speed-reading. Izmir: Bilgivizyon Publications.

Baştuğ, M., \& Akyol, H. (2012). Fluent reading skills predict reading comprehension. Journal of Theoretical Educational Science, 5(4), 394-41 1.

Beyreli, L., Çetindağ, Z., \& Celepoğlu, A. (2010). Written and verbal expression. Ankara: Pegem Academy Publishing. 
Blommers, P. J., \& Lindquist, E. F. (1954). Rate of comprehension of reading: Its measurement and its relationship to comprehension. The Journal of Educational Psychology, 35(8), 449-473.

Carver, R. P. (1989). Silent reading rates in grade equivalents. Journal Reading Bhovior, 21(2), 155-166.

Celik, C. E. (2006). A comparison between reading aloud and silent reading and reading through it. D. U. Ziya Gökalp Faculty of Education Journal, 7(July), 18-30.

Cifci, M. (2000). Reading out loud. Bilge Magazine, 24, 178-183.

Davey, L. (2009). The application of case study evaluations. (Translator: Tuba Gökçek). Elementary Educatıon Online, 8(2), 1-3.

Değirmenci Gündoğmuş, H. (2018). Determining the reading comprehension levels of primary school fourth grade students according to various variables. Social Sciences Studies Journal, 4(15), 738-743.

Dilligil, İ. R. (2004). Fast reading and comprehension techniques with its methods (2nd ed.). Ankara: Piramit Publishing.

Gray, V. S. (1975). Teaching reading and writing. Ankara: MEB Publications.

Güneş, F. (2007). Turkish teaching and mental structuring. Ankara: Nobel Yayın Distribution.

Harris, A. J., \& Sipay, E. R. (1990). How to increase reading ability (9th ed.). New York: Longman.

Imrak, M. (2006). Reading habits of famous people. Istanbul: Cira Publications.

Kavcar, C. (1995). Turkish teaching. Ankara: Rekmay Printing House.

Keskin, H. K. (2012). The effect of fluent reading methods on reading skills. Unpublished Doctoral Thesis, Gazi University / Institute of Educational Sciences, Ankara.

Kondu, C. (2008). Reading and learning fast by understanding. Istanbul: Akis Publications.

Korkmaz, B. (2008). Teaching reading, (Ed: Atilla Tazebay, and Süleyman Çelenk), Turkish Teaching (pp. 70-127). Ankara: Maya Academic Publication Distribution.

Kurudayığlu, M., \& Soysal. (2015). The impact of speed reading techniques on the rate of reading and level of comprehension of the fifth grade students. International Journal Soc. Science \& Education, 5(4), 23-25.

Lane, H. B., \& Wright, T. W. (2007). Maximizing the effectiveness of reading aloud. International Reading Association, 60(7), 668675.Available at: https://doi.org/10.1598/RT.60.7.7.

Maviş, A. (2005). Reading comprehension and learning techniques. Istanbul: Hayat Publishing.

Okur, A. (2013). Lifelong reading education. Ankara: Pegem A Publishing.

Oz, M. F. (2011). Applied Turkish teaching (4th ed.). Ankara: Memoir publishing.

Ozbay, M. (2009). Understanding techniques I: Reading education. Ankara: Pioneer Book.

Ozdemir, E. (1990). Reading Art. Istanbul: Inkılâp Bookstore.

Rozan, N. (1982). The role of teachers in reading habits. Education and Science, 7(39), 19-23.

Ruşen, M. (2016). Speed-reading (29th ed.). Istanbul: Alfa Publishing.

Sahin, A. (2011). Comparison of reading comprehension achievement and reading speed of fifth grade students who learned to read and write with different methods. Hacettepe University Faculty of Education Journal, 41(41), 423-433.

Sever, S. (2004). Turkish teaching and full learning. Ankara: Anı Yayıncllık.

Smith, H., \& Dechant, E. V. (1961). Psychology in teaching reading. Englewood Cliffs, N.J: Prentice-Hall.

Stanovich, E. K., Nathan, R. G., \& Zolman, J. E. (1988). The developmental lag hypothesis in reading. Longitudinal and matched reading level comparisons. Child Development, 59(1), 71-86.

Yıldırım, A., \& Simşek, H. (2013). Qualitative research methods in social sciences (9th ed.). Ankara: Seçkin Publishing.

Yllmaz, M. (2018). Teaching Turkish in the light of new developments (2nd ed.). Ankara: Pegem A Publishing. 